\title{
АДРОНЫ КЛАСТЕРЫГ ЯЛГАХАД ЗОРИУЛСАН ПАРАМЕТРИЙГ ТОДОРХОЙЛСОН НЬ
}

\author{
Р.Тогоо ${ }^{1}$, Ж.Шинэбаяр ${ }^{2}$, Д.Отгонсурэн \\ 1) ШУА, Физик технологийн хүрээлэн \\ 2) МУБИС, Боловсрол судлальн сургууль \\ Цахимиуудан: togoomas@gmail.com,jshinebayar@gmail.com
}

Товч агуулга: 3.6А ГэВ энергитэй нүүрстөрөгчийн цөмөөр 2 метрийн пропант хөөст камер болон цөмийн фотоэмульсийг шарсан үед эдгээр төхөөрөмжүүдийн дотор бүртгэгдсэн харимхай бус харилцан үйлчлэлийн процесст ажиглагдах

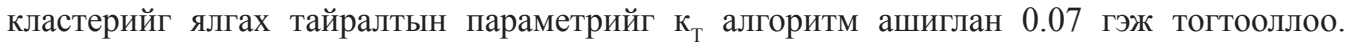

\section{ОРШИЛ}

Кластер хэмээх ойлголт асар уудам орчлонгоос эхлээд эгэл ертөнцөд оршин тогтнодог үзэгдэл. Кластерыг эгэл бөөмийн физикт тухайлбал 2 метрийн хөөст камерын өгөлтийг ашигласан судалгаа дөчөөд жилийн өмнөөс олон төрлийн аргаар судлаж

\section{ТУРШИЛТЫН МАТЕРИАЛ}

Өнгөрсөн зууны сүүлчийн 20-иод жилд ОХУ-ын Дубна хот дахь Цөмийн шинжилгээний нэгдсэн иститутийн Их энергийн лабораторийн Синхрофазотрон хурдасгуураар төмөр $\mathrm{F}_{\mathrm{e}}$ хүртэлх цөмийг түүний нэг нуклонд оногдох энерги нь 3.6 ГэВ-тэй тэнцүу болгож хурдасгаж чадсан. Жишээлбэл нүүрстөрөгчийн цөмийг тухайн

\section{СУДАЛГААНЫ ҮР ДҮН}

А. 2 метрийн пропант хөөст камерт бүртгэгдсэн Сp-, СС- ба СТа-үйлчлэлийн хувьд адроны кластерыг ялгахдаа юуны өмнө түүнийг илрүүлэх зорилгоор сонгосон огторгуйд тусгайлан “тайрах” параметрийг тодорхойлох хэрэгтэй. Үүний тулд эхлээд огторгуйг сонгодог. Бид энэ удаа дээрх харилцан үйлчлэлээр үүссэн хоёрдогч бөөмсийн азимуталь өнцөг $(\phi)$, хурдац (у) ба импульсийн хөндлөн байгуулагчийн квадрат () хэмээх гурван инвариант ирсэн [1-3]. Энэ удаа бид к ашиглан судалгааг үргэлжлүүлж байна. Гэхдээ кластерийг ялгах параметрийг эхлээд тодорхойлох шаардлагатай учраас уг параметрийг хэрхэн тодорхойлсныг дор дурьдав. энергитэй болгоод, 2 метрийн пропант хөөст камер болон цөмийн фотоэмульсийг шарсан. Эдгээр төхөөрөмжид бүртгэгдсэн харилцан үйлчлэлийн тохиолдлуудын тоо нь хөөст камерын хувьд $37792 \mathrm{C}$-пропан $\left(\mathrm{C}_{3} \mathrm{H}_{8}\right)$, фотоэмульсийнх 1931 C-Em. Туршилтын харалт, хэмжилт ба боловсруулалтын арга зүйг $[4,5]$ ажлуудаас судлаж болно. хэмжигдэхүүн-үүдээр (олгойдох үзэгдэл) буюу кластерыг ялгадаг к - алгоритм [6]-ыг сонгож авсан. Энэ алгоритмээр кластерыг ялгахын өмнө к -алгоритмын агуулгыг товч тодорхойлоё. Эхлээд хоёр бөөмсийн хоорондох зай (хэмжээ буюу distance) $\mathrm{d}_{\mathrm{ij}}$-Г дээр дурьдсан гурван хэмжигдэхүүний холбоо нь дараахь байдлаар илэрхийлнэ:

$$
\mathrm{d}_{\mathrm{ij}}=\min \left\{\mathrm{p}_{\mathrm{T}, \mathrm{i}}^{2 \mathrm{p}}, \mathrm{p}_{\mathrm{T}, \mathrm{j}}^{2 \mathrm{p}}\right\} \cdot \mathrm{R}_{\mathrm{ij}}^{2} / D_{0}^{2}(1)
$$
энд $\mathrm{R}_{\mathrm{ij}}$ бол азимуталь өнцөг ба хурдцын 
хавтгай дээрх і ба ј гэсэн дурын 2 бөөмсийн хоорондох хэмжээ, энэ хэмжигдэхүүний квадрат нь $\mathrm{R}_{\mathrm{i} j}^{2}=\left(\phi_{\mathrm{i}}-\phi\right)^{2}+\left(\mathrm{y}_{\mathrm{i}}-\mathrm{y}_{\mathrm{j}}\right)^{2}$ гэсэн холбоотой, $\left\{p_{T, i}^{2}, p_{T, j}^{2}\right\}$ нь і бај бөөмсийн хөндлөн импульсийн квадратууд $\left(\mathrm{p}_{\mathrm{T}, \mathrm{i}}^{2}, \mathrm{p}_{\mathrm{T}, \mathrm{j}}^{2}\right)$-аас аль бага утгыг нь сонгон авах үйлдэл, р-сонголтын параметр бөгөөд -1, 0, 1 утгыг тохируулан авдаг, хэрвээ бөөмсийн импульс хэмжсэн тохиолдолд $\mathrm{p}=1$, импульсгүй бол $\mathrm{p}=0$, харин $\mathrm{p}=-1$ үеийг анти к т $_{\text {[7] }}$ гэж нэрлэдэг ба сонгон авсан кластерыг орлох нөхцөл бөгөөд бол мөн багаж төхөөрөмжтэй холбоотой тохируулгын параметр манай тохиолдолд нэгтэй тэнцүу гэж авсан, түүний хэмжээс нь $\left[\right.$ ГэВ $\left.{ }^{2}\right]$.

Зураг 1 дээр Сp-, CC- ба СТаүйлчлэлүүдээр хоёрдогч бөөмсийн хосыг илэрхийлэл (1) хэмжигдэхүүний хамгийн бага утгаас хамгийн их утга хүртэл утгуудад харгалзсан кластеруудын тоонуудыг кластерын тоо $\left(\mathrm{N}_{\mathrm{cl}}\right)$-оос хэрхэн өөрчлөгддөг хамаарлыг үзүүллээ. Эдгээр хамаарал болгон $\mathrm{d}_{\mathrm{ij}}$-ийн дундаж утгууд $\left(<\mathrm{d}_{\mathrm{ij}}>\right)-$-г өгдөг. Зураг 2 дээр кластеруудын тоо $\left(\mathrm{N}_{\mathrm{cl}}\right)$ оос $<\mathrm{d}_{\mathrm{ij}}>$ хэрхэн хамаарахыг харуулав. СТа харилцан үйлчлэлийн хувьд $\mathrm{N}_{\mathrm{cl}}$-ээс $<\mathrm{d}_{\mathrm{ij}}>-$ ийн хамаарах хамаарлыг хоёр зэргэн функцүүдийн нийлбэрээр ойролцооллоо. $\mathrm{y}=\ln \left(<\mathrm{d}_{\mathrm{ij}}>\right) \quad$ ба $\mathrm{x}=\ln \left(\mathrm{N}_{\mathrm{cl}}\right)$ гэж тэмдэглэбэл тус нийлбэрийг дараах маягаар томъёолож болно:

$$
y=a_{1} x^{b_{1}}+a_{2} x^{b_{2}}
$$

гэж бичиж болно.

Хүснэгтэд илэрхийлэл (2) дэхь чөлөөт параметрүүд $\left(\mathrm{a}_{1}, \mathrm{~b}_{1}, \mathrm{a}_{2}\right.$ ба $\left.\mathrm{b}_{2}\right)$ ийн дөхүүлэлтээр олдсон тоон утгуудыг нийтлэв.

Зураг 2-ээс харахад $<\mathrm{d}_{\mathrm{ij}}>\sim 0.6 \div 0.8$ хооронд ойролцоолол хийсэн шулуунууд маш сайн $\chi^{2} / \mathrm{NDF}-и$ йн үзүүлэлттэйгээр огтлолцож байна. Энд NDF нь чөлөөтэй параметрийн тоо буюу Number of Degree of Freedom.

$<\mathrm{d}_{\mathrm{ij}}>\quad$ хэмжигдэхүүнээс кластер дахь бөөмсийн дундач утгууд $\left(<\mathrm{N}_{ \pm}^{\mathrm{cl}}>\right)$, кластерын хурдцын дундач утгууд $\left(<\mathrm{y}_{\mathrm{cl}}>\right)$ болон кластерын тайван байх систем дэхь кластер дотор хамрагдсан бөөмсийн кинетик энергийн дундач утгууд $\left(<\mathrm{T}_{\mathrm{k}}>\right)$-ын хамаарлыг Зураг $2 \div 4$ дээр харуулав.

Эдгээр зургуудаас үзэхэд $<\mathrm{d}_{\mathrm{ij}}>\sim 0.07$ орчим хоёр зэргэн функцүүдын огтлолцол байгааг тогтоож байна. Иймд адроны кластер ялгах тайралтын параметр 0.07-той тэнцүү гэж бид үзлээ.

Энэ параметрийг ашиглан хөөст камер дотор харилцан үйлчлэлээс шинээр үүссэн саармаг $\mathrm{K}_{\mathrm{s}}^{0}$ мезон болон $\Lambda^{0}$ гипероны задралын бөөмсөөр нь уг бөөмсийн эффектив массыг дахин тодорхойлоход $\mathrm{K}_{\mathrm{s}}^{0}$ мезоны ихэнхийг харин $\Lambda^{0}$ гипероныг бараг бүгдийг байгуулж чадаж байна. Үүнийг Зураг 4-ийн дээд талуудад үзүүлсэн туршлагын дүнгээс тодорхой харагдаж байна.

Энэ тайралтын параметр нь CEm харилцан үйлчлэлд ямар байх вэ?

Б. Цөмийн фотоэмульсээр СЕm үйлчлэлийг авч үзэхэд тус үйлчлэлээр Үүссэн хоёрдогч бөөмсийн импульсийг хэмжиж чаддаггүй учраас (1) илэрхийлэл дэхь р параметр тэгтэй тэнцүу гэсэн билээ.

Зураг 5 дээр СЕТ-үйлчлэлд үүссэн релятив (s) бөөмс ба сум цөмийн хэлтэрхийнүүд кластер үүсгэх процессыг Зураг 1 шиг $\mathrm{d}_{\mathrm{ij}}$-ийн хамгийн бага утгаас хамгийн их утга хүртэлх хэмжигдэхүүнээс кластерын тооны янз бүрийн утга буюу $\mathrm{N}_{\mathrm{cl}}=0,1,2, \ldots, 8,9$ байх үед тохиолдлын тоо $d_{\mathrm{ij}}$-ээс хамаарах хамаарлыг харууллаа. Энд хоёрдогч бөөмийн ионизациар хар мөр буюу уг мөрний дагуу тасралт бараг ажиглагдахгүй бөгөөд харьцангуй хурд $\beta<0.3$ ба саарал мөр бүр маш их тасархай биш буюу мөн түүний харьцангуй хурд $0.3>\beta>0.7$ байдаг хоёр бөөмийг судалгаандаа оруулаагүйг цохон тэмдэглэх хэрэгтэй. Энэ хоёр бөөмсийн хувьд түүний хурдцыг бодох боломжгүй. Иймд эдгээр бөөмстэй ойролцоо хурдац бүхий бөөмийг хасахын тулд харьцангуй хурд нь $\beta>0.7-$ тэй релятив $\mathbf{s}$ бөөмийн псевдохурдац $\eta_{\mathrm{s}}$ нь 0.7-оос ихтэй бөөмийн болон сум цөмийн бүх хэлтэрхийнүүдийн псевдохурдцыг 
туршлагаар хялбархан тодорхойлдог учраас тэдгээрийг судалгаандаа хамруулсан.

Дээр дурьдсан аргыг бид энд дахин хэрэглэн $\mathrm{d}_{\mathrm{ij}}$-ийн дундаж утгууд $\mathrm{N}_{\mathrm{cl}}$ буюу кластерийн тооноос хамаарах хамаарлыг CEm-үйлчлэлд судлав. Зураг 6-аaс харахад илэрхийлэл (2)-оор тодорхойлогдож байна. Харин энэ зурагт үзүүлсэн шулуунууд $<\mathrm{d}_{\mathrm{ij}}>-$ ийн $4 \div 5$ үед огтлолцлоо. Атомын цөмүүд фотоэмульсийн цөмүүдтэй мөргөлдөхөд тэнд адроны кластер хайж олох параметр нь $\mathrm{d}_{\mathrm{ij}} \sim 4.5$-тэй тэнцүҮ байна. Одоо бид онолын загвар ашиглан судалгааг баталгаажуулна. Жишээлбэл энэ Зураг 6-дээр феноменологи
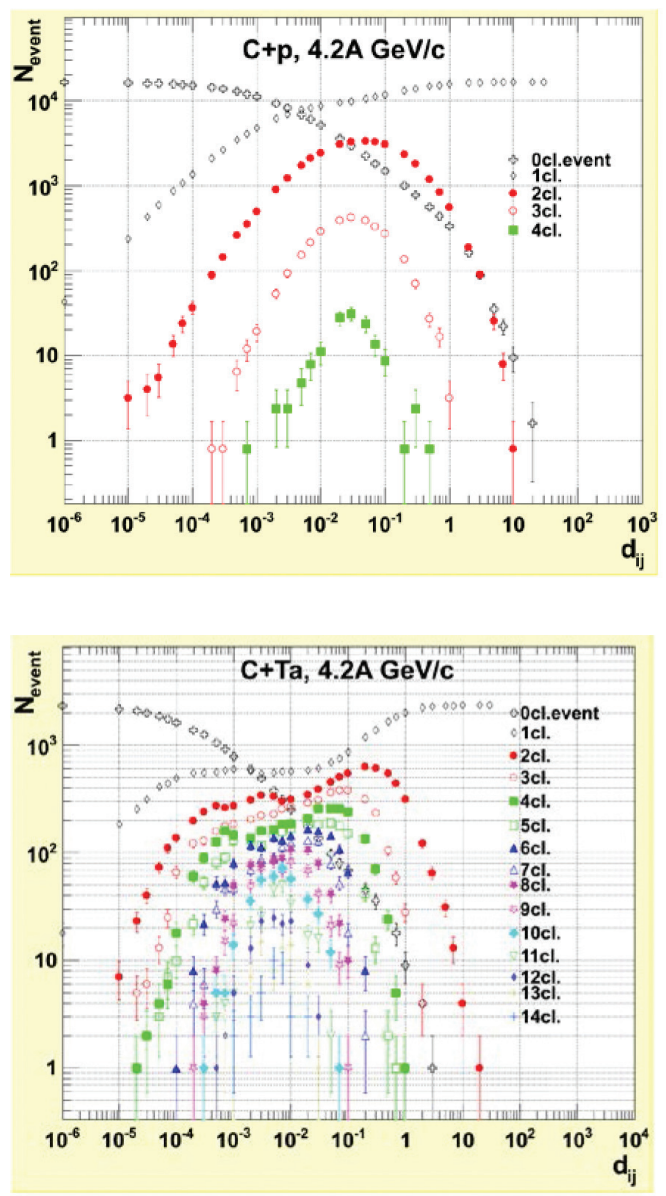

загварууд болох каскад-ууршилт ба Fritiof (фритиоф)-оор хиймэл тохиолдол гаргаж, туршлагатай адилхан нөхцлийг оруулан $\eta>0.7$ бүхий s- ба f- бөөмсийн кластерт харгалзах $<\mathrm{d}_{\mathrm{ij}}>$-ээс кластерын тоо $\mathrm{N}_{\mathrm{cl}}$-ийн хамаарлыг улаан ба хөх өнгөөр тэмдэглэн харууллаа. Феноменологи загварууд туршилтын дүнтэй сайн тохирч байна.

Одоо бид каскад-ууршилт ба фритиоф загваруудын хувьд бүх цэнэгт бөөмсөөр нь $\kappa_{\mathrm{T}}$ алгоритмаар кластер байгуулж, $<\mathrm{d}_{\mathrm{ij}}>-э э c$ кластерын тоо $\mathrm{N}_{\mathrm{cl}}$-ийн хамаарлыг давтан үзье.

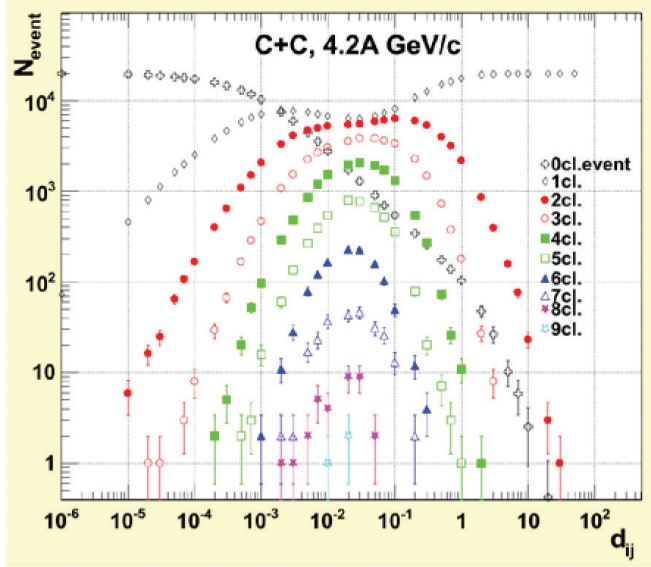

Зураг 1. dij түгэлтүҮд. ЗҮҮн дээд талын түгэлт бол Ср-үйлчлэлийн хувьд кластерын тоо $\mathrm{Ncl}=0$, 1, 2, 3, 4 байх үед, баруун дээд түгэлт нь $\mathrm{Ncl}=$ 0, 1,..., 9 уед СС-харилцан үйлчлэлд харин зүYн доод талынх нь $\mathrm{Ncl}=0,1, \ldots, 16,17$ үед CTaүйлчлэлд тус тус харгалзуулсан dij түгэлтүҮд.

Хүснэгт. Илэрхийлэл (2) дэхь чөлөөт параметрүүдийн утгууд.

\begin{tabular}{|c|c|c|c|c|c|}
\hline Параметрүүд & $\mathrm{a}_{1}$ & $\mathrm{~b}_{1}$ & $\mathrm{a}_{2}$ & $\mathrm{~b}_{2}$ & $\chi^{2} \mathrm{NDF}$ \\
\hline Дөхүүлэлт & $4.6 \pm 0.2$ & $-4.54 \pm 0.16$ & $0.24 \pm 0.08$ & $-1.37 \pm 0.14$ & $4.2 / 15$ \\
\hline
\end{tabular}


Феноменологи загваруудын хувьд үүссэн бүх бөөмсийн ЦФТ-д бүртгэгдснийг судалгаандаа оруулан дээр дурьдсан аргачлалаар мөн Зураг 1 ба Зураг 5-тай адилхнаар $\mathrm{d}_{\mathrm{ij}}$-ийн хамгийн бага утгаас хамгийн их утга хүртэлх хэмжигдэхүүнээс кластерын тооны янз бүрийн утга буюу $\mathrm{N}_{\mathrm{cl}}=$ $0,1,2, \ldots, 18,19$ байх үед тохиолдлын тоо $\mathrm{d}_{\mathrm{ij}}$ ээс хамаарах хамаарлыг Зураг 7-д үзүүллээ.
Ингээд Зураг 8-д кластерын тооноос $<\mathrm{d}_{\mathrm{ij}}>$ хэрхэн хамаарахыг харуулаад, түүнийг мөн илэрхийлэл (2) -ээр ойролцоолол хийгээд, огтлолцлын цэг ойролцоогоор 0.07 орчим байна. Энэ нь хөөст камерт болон ЦФД дотор цөм-цөмийн мөргөлдөөнөөр үүссэн адроны кластерыг илэрүүлэх тайралтын параметр хувьд бидний сонгож авсан 0.07 үнэн болохыг батлаж байна.
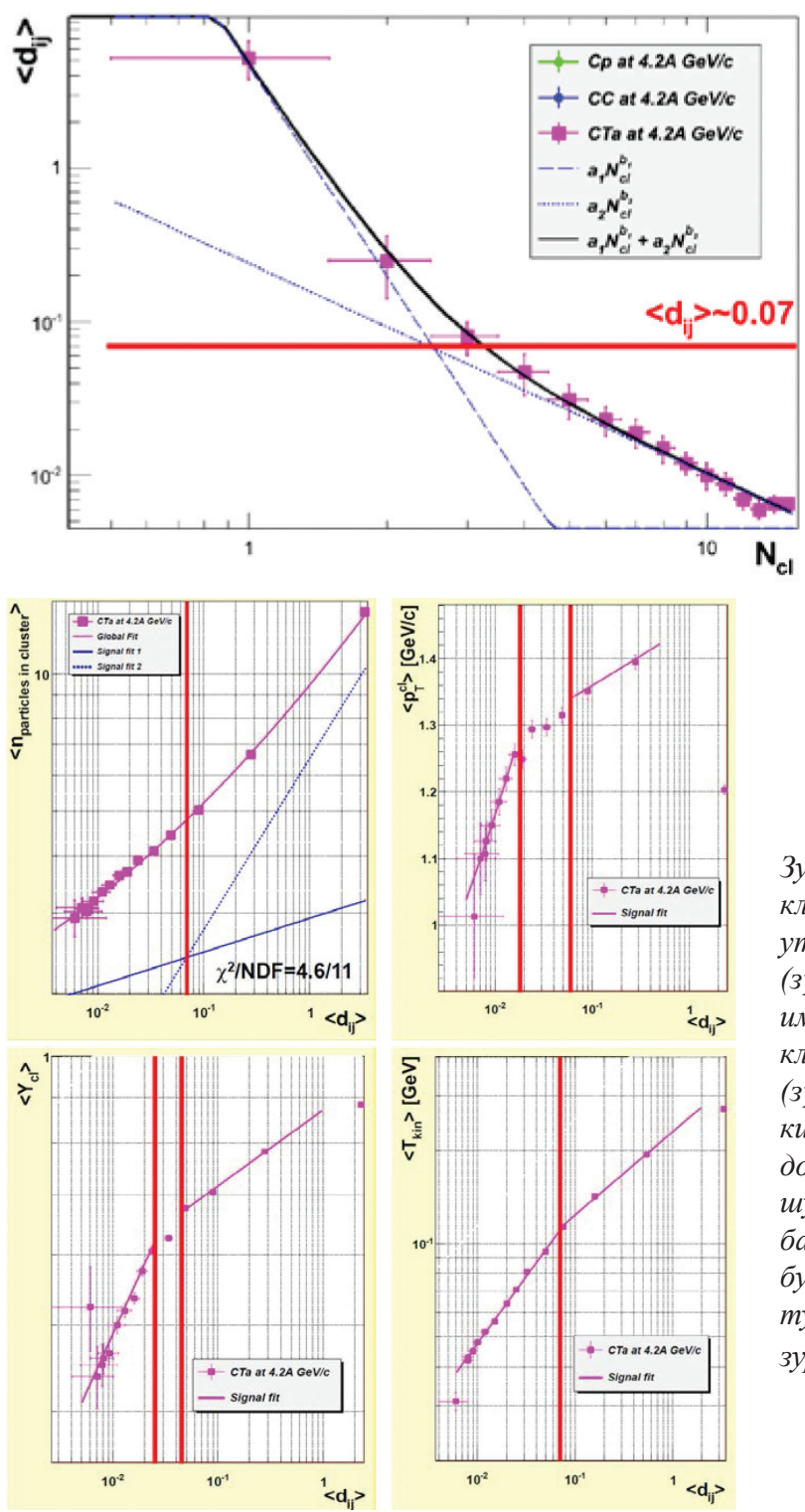

Зураг 2. $d_{i j}$ параметрийн дундач утга $<d_{i j}>{ }_{\text {нь }}$ кластерын тоо $\mathrm{N}_{c l}$ оос хамаарах хамаарал. Энд ногоон өнгөөр Ср-, хөхөөр СС- ба ягаанаар СТа-үйлчлэлийн хувьд турилагаар олсон дүнгүуд. Хар муруйгаар дөхүҮлэлт хийсэн ерөнхий дүн. Хоёр хөх шулуунууд нь илэрхийлэл (2) дэхь хоёр зэргэн функиүүдий дүрслэж байна. Хэвтээ улаан шугам 2 иулууны огтлолиььг дайруулан татсан шулуун.

Зураг 3. СТа-үйлчлэлийн хувьд $<d_{i j}>э э c$ кластер дахь изэнгт бөөмсийн дундач утга $<N_{\text {particles in cluster }}>-$-йн хамаарал (зҮүн дээд тальнх), кластерын хөндлөн импульсийн дундач $\left\langle p_{T}^{c l}\right\rangle$ (баруун дээд), кластерын хурдащын дундач $<y_{c l}>$ (зуҮн доод) ба кластер дахь бөөмсийн кинетик энергийн дундач $<T_{\text {kin }}>$ (баруун доод). Энд босоо улаан иугамаар хоёр иулууны огтлолисон ба огтлолияож болох байрлальг тэмдэглэсэн. Эхний зургаас бусад гурван зурагт ягаан шулуунуудыг туриилтьлн иэгүҮдий дайруулсан гараар зурсан болно. 


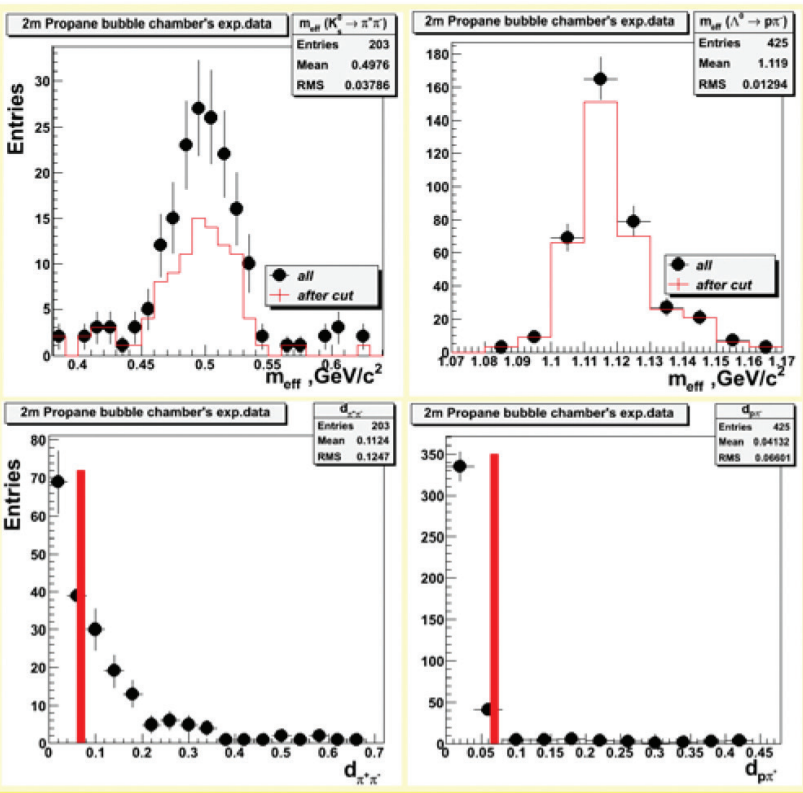

Зураг 4. Камерын эффеектив мужид хоёрдогч саармаг бөөмс Үүссэн уед тэдгээрийн эффектив массын түгэлтүуд. - мезон нь -мезон ба -мезонд задрах задральн масс (баруун дээд тальнх), $\Lambda^{\circ}$ гипертон нь протон ба -мезонд задрах задральн масс (зҮүн дээд). Баруун доод талд задарсан -мезон ба -мезоны хоорондох “зай”-ийн, зүҮн доод талд задралын протон ба -мезоны хоорондох “зай” -ийн түгэлтүҮд. Дээд талуудад улаанаар ҮзҮүлсэн түгэлтүҮд $d_{i j}$ нь $0.07-э э c$ бага нөхиөлд харгалзсан эффектив массын түгэлтүҮд.

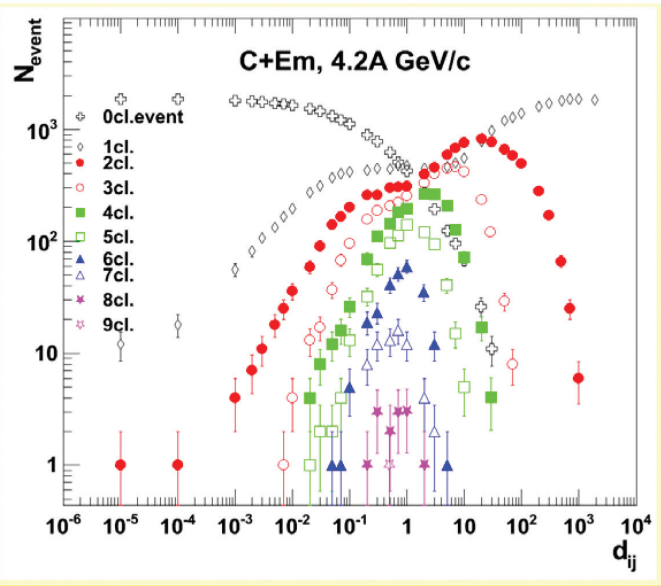

Зураг 5. СЕт-үйлчлэлийн хувьд кластерын тоо $N_{c l}=0,1, \ldots, 9$ уед харгалзуулсан $d_{i j}$ - ээс тохиолдльн тоо $\left(N_{\text {еvеn }}\right)$ хамаарахыг харуулсан түгэлтүҮд.

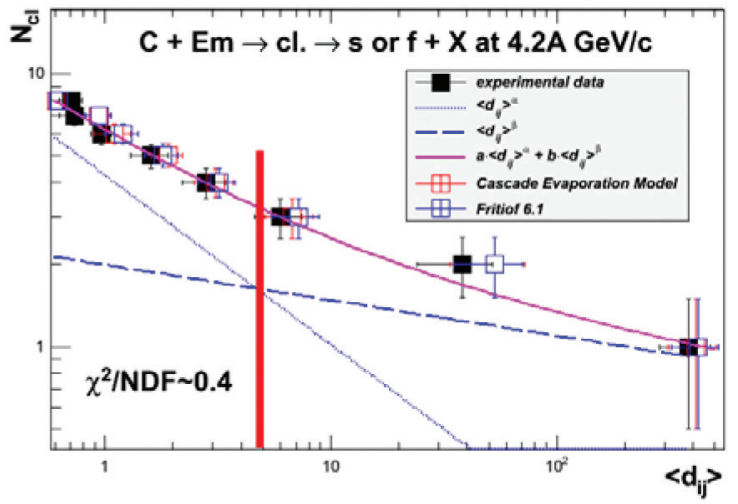

Зураг 6. $d_{i j}$ параметрийн дундач утга $<d_{i j}>$-ээс кластерын тоо $N_{c l}$-оос хамаарах хамаарал. Энд хар дөрвөлжингөөр СЕт-үйлчлэлийн турилагын өгөлт, онгорхой дөрвөлжсингүдийн улаанаар каскад-ууршилтын харин хөхөөр Fritiof загваруудаар гаргаж авсан дүнгүҮдэд харгалзана. 

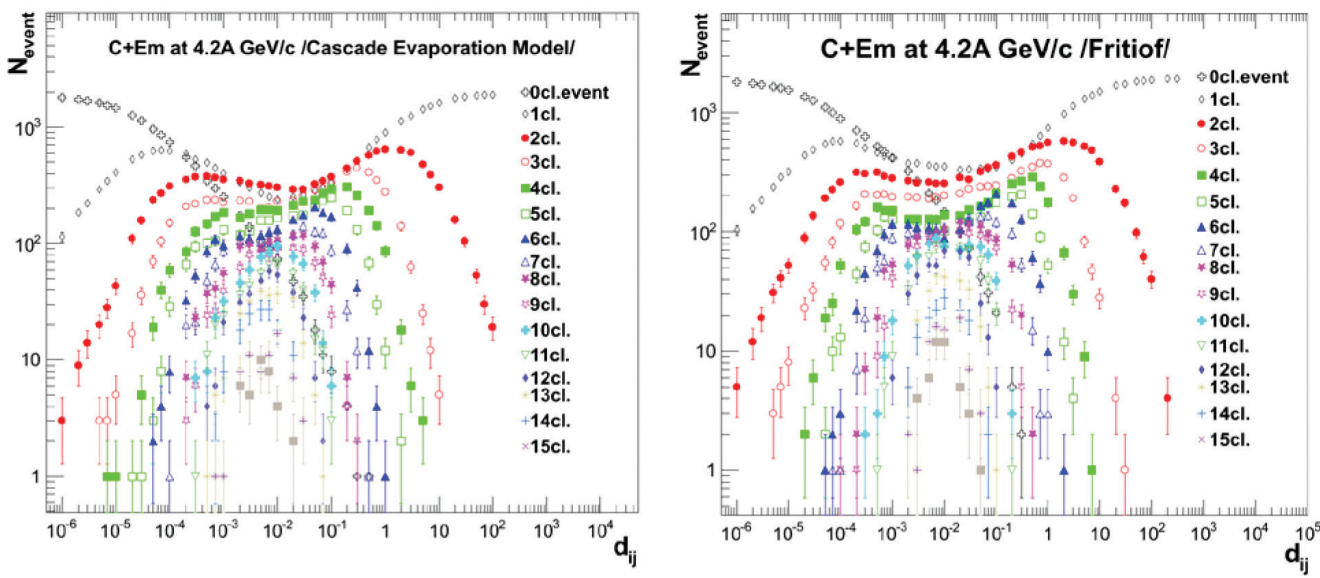

Зураг 7. Феноменологи каскад-ууршилтын (баруун гар тальнх) болон Fritiof (зүүн гар талыни) загваруудаар СЕт-үйлчлэлийн тохиолдлуудыг гарган аваад, энэ мөргөлдөөний хувьд кластерын тоо $N_{c l}=0,1, \ldots, 18,19$ Үед харгалзуулсан $d_{i j}$ - ээс тохиолдлын тоо $\left(N_{\text {еvен }}\right)$ хамаарсан түгэлтүУд.

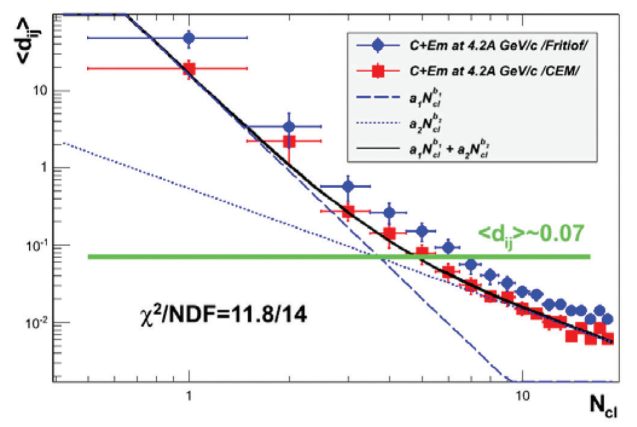

Зураг 8. Загварчилсан СЕт-үйлчлэлийн хувьд кластерын тооноос $<d_{i j}>$-ийн хамаарлууд. Энд каскад-ууршилт (улаан дөрвөлжингөөр) болон фритиоф (хөх дугуйгаар) загваруудыг нэгэн зэрэг УзҮүлсэн. Харин дөхүүлэлтийг зөвхөн каскад-ууршилтын загварт хийлээ.

Аиигласан бүтээлийн жагсаалт

1. В.Г.Гришин и др., ОИЯИ, Р1-82-393, Дубна, 1982; ОИЯИ, Р1-82-754, Дубна, 1982; ОИЯИ, P1-89-639, Дубна, 1989; А.М.Балдин и др. ОИЯИ, Р1-83-483, Дубна, 1983; ОИЯИ, P1-85820, Дубна, 1983; A.M.Baldin et al., JINR,E1-85-675, Dubna, 1985; JINR, E1-87-142, Dubna, 1987; L.A.Didenko, G.V.Grishin, A.A.Kuznetsov, JINR, E1-91-329, Dubna, 1991; JINR, E1-91323, Dubna,1991.

2. Н.Ангелов, В.Б.Любимов и P.Toгоo, JINR Rapid Comm. № 7 (33), Dubna, 1988, p 5.; № 3889, Dubna, 1989, p 11; Comm. JINR,№-2[41]-90, Дубна, 1990, p. 4; №-4[43]-91,Dubna, 1991, p.27.; №-5[51]-91, Dubna, 1991, p. 14; Yad. Fiz., Vol. 55, № 11, 1992, p. 2953;

3. R.Togoo et al. Proc. ICCP-5, 3 June 2013, Ulaanbaatar, Mongolia.

4. N. Angelov et al. JINR-P1-12281, Mar 1979. 17pp; Yad.Fiz.30:1590-1598,1979. Preprint JINRE1-12548, Dubna 1979; Yad.Fiz. Vol.30, No.6(12), 1979, pp.1590-1598; G.N.Agakishiev et al. Preprint JINR, P1-84-35 and E1-84-321 Dubna, 1984; Yad.Fiz. Vol.40, No.5, 1984, pp.12091221; Z.Phys. Vol.27C, 1985, pp.177

5. Банник Б.П и др. ОИЯИ, Р1-130558, Дубна, 1980; Богачев Н.И и др. ОИЯИ, Р1-6877, Дубна, 1972; Galstyan J.A et al. Nucl. Phys., 1973, A208, p.626; BVDKLMT Coll., Acta Phys. Slov., 1978, 28. Р.132; Адамович М.Н. и др. ОИЯИ; Сотрудничество ОИЯИ, Р1-8313, Дубна, 1974.

6. S. Ellis and D. Soper, Phys. Rev. D 48 (1993) 3160, [hep-ph/9305266].

7. M. Cacciari, G. P. Salam, and G. Soyez, JHEP 0804 (2008) 063, [arXiv:0802.1189]. 


\title{
DETERMINATION OF CUT PARAMETER FOR HADRONIC CLUSTER'S SELECTION
}

\author{
R.TogooI, J.Shinebayar ${ }^{2}$, D.Otgonsuren ${ }^{1}$ \\ 1) Institut of Physics and Technology, MAS \\ 2) School of Educational Studies, Mongolian National University of Education \\ E_mails: togoomas@gmail.com,jshinebayar@gmail.com
}

\begin{abstract}
Absract: A cut parameter of the hadronic cluster's selection for inelastic scattering processes from 2 meter propane bubble chamber and nuclear photoemulsion at incident $3.6 \mathrm{~A} \mathrm{GeV}$ energy of carbon nucleus was determined using $\mathrm{k}_{\mathrm{T}}$ jet algorithm. The value of a cut parameter is obtained equals to 0.07 .
\end{abstract}

